\title{
Minocycline is cytoprotective in human trabecular meshwork cells and optic nerve head astrocytes by increasing expression of XIAP, survivin, and $\mathrm{BCl}-2$
}

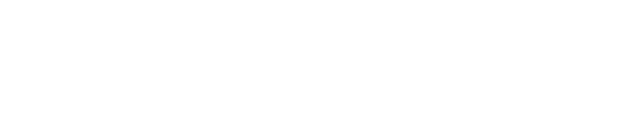

\section{Marcus Kernt \\ Aljoscha S Neubauer \\ Kirsten $\mathrm{H}$ Eibl \\ Armin Wolf \\ Michael W Ulbig \\ Anselm Kampik \\ Cristoph Hirneiss}

Department of Ophthalmology, Ludwig-Maximilians-University,

Munich, Germany
Correspondence: Marcus Kernt Department of Ophthalmology, Ludwig-Maximilians-University Munich, Mathildenstr. 8, 80336

Muenchen, Germany

$\mathrm{Tel}+49895$ I $6038 \mathrm{ll}$

Fax $+49895 \quad 1605160$

Email marcus.kernt@med.

uni-muenchen.de
Introduction: Primary open-angle glaucoma (POAG) is one of the leading causes of blindness. Activation of optic nerve head astrocytes (ONHA) and loss of trabecular meshwork cells (TMC) are pathognomonic for this neurodegenerative disease. Oxidative stress and elevated levels of transforming growth factor beta (TGF $\beta$ ) play an important role in the pathogenesis of POAG. This study investigates the possible antiapoptotic and cytoprotective effects of minocycline on TMC and ONHA under oxidative stress and increased TGF $\beta$ levels.

Methods: TMC and ONHA were treated with minocycline 1-150 $\mu \mathrm{M}$. Possible toxic effects and $\mathrm{IC}_{50}$ were evaluated after 48 hours. Cell proliferation and viability were examined in order to assess the protective effects of minocycline on TMC and ONHA. Expression of Bcl-2, XIAP, and survivin, as well as their mRNA expression, were assessed by real time polymerase chain reaction (RT-PCR) and Western Blot analysis 48 hours after treatment with minocycline alone and additional incubation with TGF $\beta-2$ or oxidative stress.

Results: Minocycline 1-75 $\mu \mathrm{M}$ showed no toxic effects on TMC and ONHA. Under conditions of oxidative stress, both TMC and ONHA showed an increase in viability and an ability to proliferate when treated with minocycline 20-40 $\mu \mathrm{M}$. RT-PCR and Western blotting yielded an overexpression of Bcl-2, XIAP, and survivin when TMC or ONHA were treated with minocycline $20-40 \mu \mathrm{M}$ under conditions of oxidative stress and when additionally incubated with TGF $\beta-2$

Conclusion: Minocycline up to $75 \mu \mathrm{M}$ does not have toxic effects on TMC and ONHA. Treatment with minocycline $20-40 \mu \mathrm{M}$ led to increased viability and proliferation under oxidative stress and TGF $\beta-2$, as well as overexpression of Bcl-2, XIAP, and survivin. This protective pathway may help to prevent apoptotic cell death of TMC and ONHA and therefore be a promising approach to avoidance of progression of glaucomatous degeneration.

Keywords: glaucoma, apoptosis, minocycline, trabecular meshwork, optic nerve head astrocytes

\section{Introduction}

Glaucoma is a chronic optic neuropathy characterized by retinal ganglion cell (RGC) loss, excavation of the optic nerve, and concomitant visual field defects. ${ }^{1}$ It is the second leading cause of blindness, and almost 75 million people are affected worldwide. ${ }^{2-4}$ Elevated intraocular pressure (IOP) is the main risk factor for the development ${ }^{5}$ and progression ${ }^{6}$ of glaucomatous damage, and most cases of glaucoma are associated with elevated IOP. ${ }^{7,8}$ Elevated IOP results from increased aqueous outflow resistance, and is due to several morphologic changes in the trabecular meshwork (TM). including 
trabecular cell loss. ${ }^{6,9,10}$ Additional factors, such as nutritional status ${ }^{11}$ and retinal ischemia, ${ }^{12,13}$ have been implicated as pathognomonic, and there is growing evidence that oxidative stress $^{14-16}$ and elevated levels of transforming growth factor beta (TGF $\beta)^{17,18}$ play a crucial role in the pathogenesis of glaucoma. It has also been shown in several animal models and in human glaucoma that both RGC and TM cells (TMC) die as a result of apoptosis. ${ }^{16,19-24}$

Minocycline is a semisynthetic, second-generation tetracycline that crosses the blood-brain barrier effectively, ${ }^{25}$ penetrates well into the eye, ${ }^{26}$ and has had proven antimicrobial and anti-inflammatory efficacy for many years. ${ }^{27,28}$ In ophthalmology, minocycline has been suggested as a treatment for several palpebral disorders and age-related macular degeneration, due to its antiinflammatory activities. ${ }^{29}$ In addition to its antibiotic and anti-inflammatory activities, it has shown neuroprotective properties in experimental models of several neurodegenerative diseases, including multiple sclerosis, Parkinson's disease, Huntington's chorea, amyotropic lateral sclerosis, ischemic stroke, traumatic brain injury, and optic nerve transection. ${ }^{30-35}$

The neuroprotective effects of minocycline are considered to be anti-inflammatory and antiapoptotic. Recent reports have demonstrated the antioxidant properties and influence of minocycline on caspases and nitric oxide synthase activity. ${ }^{36}$ Minocycline has an inhibiting effect on the release of apoptotic proteins, including cytochrome $\mathrm{c}$ and Smac/DIABLO, and induces antiapoptotic proteins, such as Bcl-2 or XIAP. ${ }^{30,37,38}$ These effects have been demonstrated mainly for cells derived from the nervous system but also for non-neuronal cells, such as kidney epithelial cells. ${ }^{38}$ A rodent study evaluating the effects of minocycline on RGC in experimental glaucoma revealed enhanced survival of RGC because of delayed apoptosis ${ }^{39}$ but, so far, little is known about the possible protective and antiapoptotic effects of minocycline on the TM and neuroretinal cells of the human eye.

In this study, we investigated the effects of minocycline on primary human optic nerve head astrocytes (ONHA) and primary human TMC with regard to viability and cell death, and we evaluated whether toxic effects occur and, if so, at which concentrations of minocycline. In order to investigate the possible antiapoptotic effects of minocycline, the expression of Bcl-2, XIAP, survivin, as well as their mRNA expression, were determined when cells were treated with minocycline, under oxidative stress or elevated levels of TGF $\beta$, to simulate glaucomatous conditions.

\section{Methods}

\section{Human optic nerve head astrocytes}

Primary cell cultures of human lamina cribrosa astrocytes were obtained from the Ludwig-Maximilian-University eye bank in Munich, Germany. Monolayer cultures were established from eyes of four human donors (aged 35, 53, 58, and 72 years, obtained 3-10 hours post mortem) without any history of eye diseases. The eyes were prepared and grown as previously described. ${ }^{40-42}$

\section{Human trabecular meshwork cells}

Cultures of human TMC were established from the same donors as for the ONHA according to protocols published previously. ${ }^{40,43,44}$ TMC of passages 3-6 were seeded in 6-well plates and grown to a confluent monolayer. After seven days' confluence, the wells were treated with minocycline as described below. Primary TMC and ONHA of passages 3-6 were used in the experiments. All procedures for gathering human tissue were undertaken with appropriate consent, complied with the Declaration of Helsinki, and were approved by the local ethics committee.

\section{Cell culture treatment}

For the MTT [3-(4,5-dimethylthiazol-2-yl)-2,5-diphenyl tetrazolium bromide] assay and viability testing, TMC (passages 3-6) and ONHA (passages 3-6) were seeded in 6-well plates and exposed to minocycline concentrations of $1,5,7.5,10,15,20$, $40,50,75,100$, and $150 \mu \mathrm{M}$. To investigate the effects of minocycline on TMC and ONHA and on RNA and protein levels, minocycline concentrations of 20 and $40 \mu \mathrm{M}$ were tested.

Before treatment, TMC and ONHA were kept for 24 hours in serum-free conditions. The cells were washed with phosphatebuffered saline (PBS) and incubated for 48 hours with minocycline concentrations soluted in DMEM/F12 medium for both TMC and ONHA cell lines. The tested substance concentrations were then removed by carefully rinsing the cells with serum-free medium three times. Thereafter, the cell proliferation assay, RNA isolation, and protein extraction was performed.

For testing the effects of minocycline under conditions of oxidative stress, cells were treated for 48 hours with the different minocycline concentrations and addition of $600 \mu \mathrm{M} \mathrm{H}_{2} \mathrm{O}_{2}$ for the last four hours. Thereafter the serum-free medium containing $\mathrm{H}_{2} \mathrm{O}_{2}$ and minocycline was removed by carefully rinsing the cells with serum-free medium three times. After another four hours of incubation with serum-free medium, cell proliferation assay, RNA isolation, and protein extraction was performed. 
To test the effects of minocycline under treatment with TGF $\beta-2$, the cells were first treated for 24 hours with the various concentrations of minocycline followed by addition of $1 \mathrm{ng} / \mathrm{mL}$ TGF $\beta$ - 2 . After another 24 hours of incubation with minocycline and TGF $\beta-2$, RNA isolation and protein extraction was performed.

\section{MTT assay}

The MTT assay was used to determine the cell survival rate. This assay, as performed in our study, is a well established test for cell viability. It was performed as described in the literature by Mosmann, ${ }^{45}$ with some modifications. The medium was removed, cells were washed with PBS, and $1000 \mu \mathrm{L} /$ well MTT solution (1.5 mL MTT stock, $2 \mathrm{mg} / \mathrm{mL}$ in PBS, plus 28.5 mL DMEM) was added. TMC and ONHA were incubated at $37^{\circ} \mathrm{C}$ for one hour. The formazan crystals that formed were dissolved by the addition of dimethylsulfoxide (1000 $\mu \mathrm{L} /$ well). Absorption was measured by a scanning multiwell spectrophotometer at $550 \mathrm{~nm}$ (Molecular Probes, Garching, Germany). Results were expressed as the mean percentage of control proliferation. Experiments were performed in triplicate and repeated three times. TMC and ONHA of the same passage incubated with balanced saline without the addition of dyes served as the control.

\section{Viability assay}

Confluent TMC and ONHA were prepared and treated as described above. Cell viability was quantified based on a twocolor fluorescence assay in which the nuclei of unviable cells appear red because of staining by the membrane-impermeable dye, propidium iodide (Sigma-Aldrich, Steinheim, Germany), while the nuclei of all cells were stained with the membranepermeable dye Hoechst 33342 (Intergen, Purchase, NY). Confluent cultures of TMC or ONHA growing on coverslips in 24-well tissue culture plates were exposed to the various concentrations of minocycline as described above for the MTT assay. To evaluate cell viability, the cells were washed in PBS and incubated with $2.0 \mu \mathrm{g} / \mathrm{mL}$ propidium iodide and 1.0 $\mu \mathrm{g} / \mathrm{mL}$ Hoechst 33342 for 20 minutes at $37^{\circ} \mathrm{C}$. Subsequently, the cells were analyzed with an epifluorescence microscope (Aristoplan, Leitz, Wetzlar, Germany). The labeled nuclei were then counted in fluorescence photomicrographs, and dead cells were expressed as a percentage of the total nuclei in the field. The data are based on counts from three experiments performed in duplicate wells, with 3-5 documented representative fields per well. TMC and ONHA of the same passage incubated with serum-free medium served as the control.

\section{RNA isolation and real-time polymerase chain reaction}

Total RNA was isolated from $10 \mathrm{~cm}$ Petri dishes by the guanidium thiocyanate-phenol-chloroform extraction method. Structural integrity of the RNA samples was confirmed by electrophoresis in 1\% Tris-acetate-ethylenediamine tetraacetic acid agarose gels. The yield and purity were determined photometrically (BioPhotometer, Eppendorf, Germany). Real-time polymerase chain reaction (RT-PCR) enables quantitative detection of small amounts of mRNA. After the usual isolation of mRNA, this mRNA was transferred to cDNA via reverse transcriptase. This cDNA was then used for the specific PCR. Quantitation of Bcl-2, survivin, and XIAP mRNA was performed with specific primers (see Table) with a LightCycler Instrument (LightCycler System, Roche Diagnostics, Mannheim, Germany). Primers and probes were found with the program ProbeFinder version 2.04. All primers and probes were designed to cross intron/exon boundaries, in order to avoid amplification of genomic DNA. All PCR products were sequenced to ensure product validity. Each $14 \mu \mathrm{L}$ reaction volume contained $1 \times$ FastStart DNA Master Hybridization Probes Mix (Roche Diagnostics), $4 \mathrm{mM} \mathrm{MgCl}_{2}, 0.5 \mathrm{mM}$ of each primer, $0.2 \mathrm{mM}$ TaqMan probe, and $2 \mu \mathrm{L}$ cDNA.

The amplification signals were detected in real time, which enabled accurate quantification of the amounts of the initial RNA template, because the system can select signals easily during the exponential amplification phase of PCR. The cDNA of cells either treated with minocycline alone $(20 \mu \mathrm{M}$ and 40 $\mu \mathrm{M})$ or additionally treated with TGF $\beta-2(1 \mathrm{ng} / \mathrm{mL})$ or 600

Table I Primer used for reverse transcription polymerase chain reaction

\begin{tabular}{llllll}
\hline Target & Length & Position & AT( $\left.{ }^{\circ} \mathbf{C}\right)$ & \%GC & Sequence \\
\hline Bcl-2 & 19 & $3465-3483$ & 60 & 58 & AGAGGTCACGGGGGCTAAT \\
& 20 & $3505-3524$ & 60 & 50 & CCAGGTAACAAAACCCCACA \\
XIAP & 25 & $46-870$ & 60 & 36 & TTTTQQQACATGGATATACTCAQTT \\
& 25 & $910-934$ & 59 & 40 & A GCACTTTACTTTATCACCTTCACC \\
Survivin & 20 & $284-303$ & 59 & 50 & GCCCAGTGTTTCTTCTGCTT \\
& 20 & $350-369$ & 60 & 45 & CCGGACGAATGCTTTTTATG \\
\hline
\end{tabular}


$\mu \mathrm{M} \mathrm{H}_{2} \mathrm{O}_{2}$ was amplified with specific primers for 40 cycles. Two oligonucleotides with differently-labeled fluorophores were hybridized to the amplified fragment during the annealing phase. When the two probes came into close proximity, fluorescence resonance energy transfer developed between the two fluorophores. The emitted fluorescence was then measured by the LightCycler instrument. Hybridization probes were displaced during the extension step. Depending on the initial concentration of target genes, the signal intensity increased in different cycles, and these cycles were used as the crossing point. The standard curve was made with three different probes of untreated TMC or ONHA. To normalize for differences in the amount of total RNA added to each reaction, 18S rRNA was simultaneously processed in the same sample as an internal control. The level of Bcl-2, survivin, and XIAP mRNA was determined as the relative ratio, which was calculated by dividing the level of Bcl-2, survivin, and XIAP mRNA by the level of the $18 \mathrm{~S}$ rRNA housekeeping gene in the same samples. Ratios were expressed in a decimal format. All experiments were performed at least in triplicate and repeated three times.

\section{Protein extraction and western blot analysis}

TMC and ONHA grown on $35 \mathrm{~mm}$ tissue culture dishes were washed twice with ice-cold PBS, collected, and lysed in radioimmunoprecipitation assay cell lysis buffer. After centrifugation for 30 minutes at $19,000 \times \mathrm{g}$ in a microfuge (5810R, Eppendorf, Hamburg, Germany) in cold conditions, the supernatant was transferred to fresh tubes and stored at $-70^{\circ} \mathrm{C}$ for future use. The protein content was measured by the bicinchoninic acid protein assay (Pierce, Rockford, IL). Denatured proteins (1e $2 \mathrm{mg}$ ) were separated by electrophoresis under reducing conditions using a 5\% sodium dodecyl sulfate-polyacrylamide stacking gel and a $12 \%$ sodium dodecyl sulfate-polyacrylamide separating gel, transferred with semidry blotting onto a polyvinyl difluoride membrane and probed with a mouse anti-Bcl-2 antibody, a mouse anti-survivin antibody, or a mouse anti-XIAP antibody, as described previously. ${ }^{46}$ Chemiluminescence was detected with an imager (LAS-1000, RayTest) and generated light units. Exposure times were in the range 1-10 minutes. Quantification was performed on a computer (AIDA software, RayTest). All experiments were performed at least in triplicate and repeated three times in ONHA and TMC cultures from three donors. An even protein load in each lane was confirmed by staining of the polyvinyl difluoride membranes with Coomassie Brilliant Blue after the blotting procedure.

\section{Statistics}

All data were entered in an MS-Excel 2000 spreadsheet (Microsoft Corporation, Redmond, WA) and analyzed using SPSS 13.0 for Windows (SPSS Inc., Chicago, IL). All statistical tests were considered significant at $P<0.05$. In detail, the statistical comparison between the different concentrations of minocycline (each measured in triplicate and performed three times) was performed using the Mann-Whitney test. For the MTT assay, quantitative results are presented as mean ( \pm standard deviation, SD) units of absorbance. Ten individual samples per group were measured in triplicate and performed three times, and comparisons performed applying the Mann-Whitney test. For RT-PCR, the results are presented as mean ratios $( \pm S D)$ of the investigated mRNA and 18S rRNA. Again, Mann-Whitney testing was applied, and all experiments were performed in triplicate and repeated three times. Western Blot analysis was performed analogous, experiments were performed at least in triplicate in ONHA and TMC cultures from three donors.

\section{Results}

Concentrations of minocycline in primary human TMC and ONHA

Minocycline concentrations of 1, 5, 7.5, 10, 15, 20, 40, 50, 75,100 , and $150 \mu \mathrm{M}$ were chosen to investigate the possible toxic effects of minocycline on TMC and ONHA. With phase-contrast microscopy, no gross abnormalities could be detected in primary TMC and ONHA for minocycline at concentrations up to $75 \mu \mathrm{M}$. The numbers of cells counted in phase-contrast microscopy were comparable with the results of the MTT test (data not shown).

When TMC and ONHA were additionally treated with $600 \mu \mathrm{M} \mathrm{H}_{2} \mathrm{O}_{2}$, those cells treated with $20 \mu \mathrm{M}$ and $40 \mu \mathrm{M}$ minocycline did not show any signs of toxicity, cellular death, or other abnormalities. The control cells treated with $600 \mu \mathrm{M} \mathrm{H}_{2} \mathrm{O}_{2}$ alone showed pronounced morphologic signs of toxicity, including abnormal shape and appearance, cellular lysis, and destruction (Figure 1). When ONHA and TMC were treated with $20 \mu \mathrm{M}$ and $40 \mu \mathrm{M}$ minocycline and additionally with TGF $\beta-2$, the cells did not show any signs of toxicity, cellular death, or other abnormalities (data not shown). The concentration of minocycline that inhibited control cell growth by $50 \%\left(\mathrm{IC}_{50}\right)$ was determined from the dose-response curves (data not shown). For a 24-hour application, this concentration was approximately $75 \mu \mathrm{M}(95 \%$ confidence interval [CI]: 65.5-84.5) for primary TMC and $100 \mu \mathrm{M}$ for ONHA (95\% CI: 88.8-111.2). 
TMC cells

A

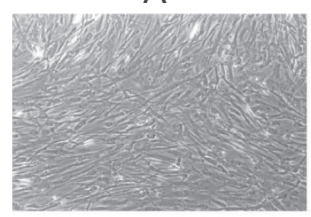

C

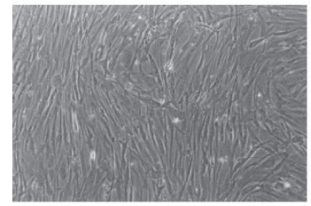

$\mathrm{E}$

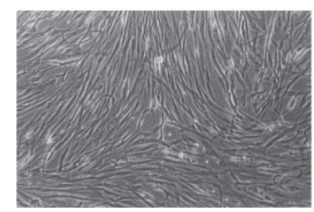

B

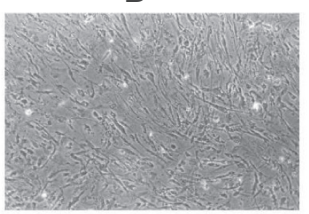

D

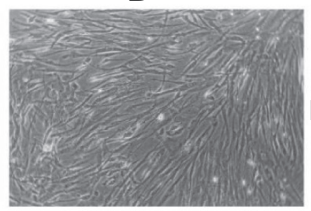

F

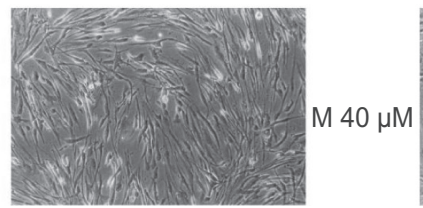

ONHA cells

G

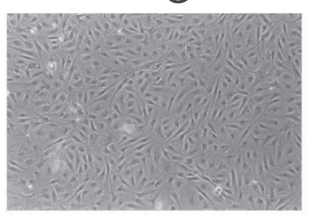

I

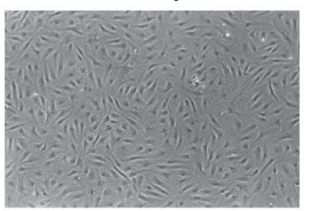

$\mathrm{L}$

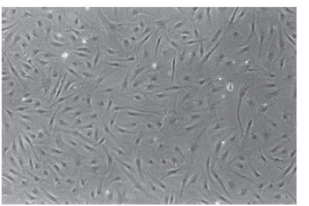

$\mathrm{H}$

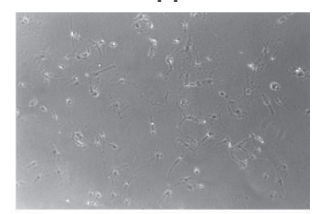

K

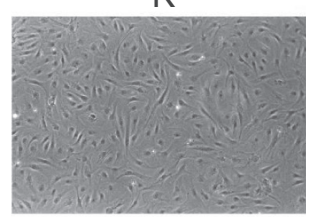

M

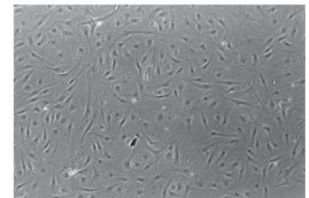

Figure I Phase-contrast microscopy of primary TMC (A-F) and ONHA cells $(\mathbf{G}-\mathbf{M})$. After treatment with minocycline $20 \mu \mathrm{M}$ and $40 \mu \mathrm{M}$ for both cell lines (TMC: C, E; ONHA: I, L), no morphologic changes could be detected. When cells were treated additionally with $600 \mu \mathrm{M} \mathrm{H}_{2} \mathrm{O}_{2}$, neither TMC nor ONHA pretreated with minocycline $20 \mu \mathrm{M}$ and $40 \mu \mathrm{M}$ (TMC: D, F; ONHA: K, M) showed any significant morphologic changes. In contrast, cells that were only treated with $600 \mu \mathrm{M} \mathrm{H}_{2} \mathrm{O}_{2}$ showed marked signs of destruction and cell death (TMC: B; ONHA: H). Scale (IOX)

Abbreviations: TMC, trabecular meshwork cells; ONHA; optic nerve head astrocytes.

\section{MTT assay}

Minocycline showed no significant toxic effects in the two investigated cell cultures (48 hours exposure) at concentrations between $1 \mu \mathrm{M}$ and $<50 \mu \mathrm{M}$ (Figures 2 and 3). All experiments were performed at least in triplicate and repeated three times. No significant decrease was detected in cellular viability for either primary TMC or ONHA, compared with the controls at concentrations $<50 \mu \mathrm{M}$. Minocycline concentrations of $50 \mu \mathrm{M}(P<0.001)$ and higher for primary ONHA led to a dose-dependent reduction of viability. When ONHA cells were treated additionally with $\mathrm{H}_{2} \mathrm{O}_{2}$, cells pretreated with minocycline concentrations $>15 \mu \mathrm{M}(P=0.02)$ up to $50 \mu \mathrm{M}(P=0.01)$ showed a significantly increased viability with a peak at $20 \mu \mathrm{M}(P<0.001)$ compared with the control. Only concentrations as high as $150 \mu \mathrm{M}$ showed significantly decreased viability $(P<0.001$, Figure 2$)$.

Minocycline concentrations of $50 \mu \mathrm{M}(P=0.005)$ and higher for primary TMC led to a dose-dependent reduction of viability (Figure 3 ). When TMC cells were treated additionally with $\mathrm{H}_{2} \mathrm{O}_{2}$, the cells pretreated with minocycline concentrations of $>7.5 \mu \mathrm{M}(P<0.001)$ up to $50 \mu \mathrm{M}$ $(P=0.002)$ showed significantly increased viability, with a peak at $40 \mu \mathrm{M}(P<0.001)$ compared with the control. Concentrations of $75 \mu \mathrm{M}(P=0.01)$ and higher showed significantly decreased viability (Figure 3 ). Minocycline concentrations of $100 \mu \mathrm{M}$ and $150 \mu \mathrm{M}$ for primary $\mathrm{TMC}$ and $150 \mu \mathrm{M}$ for ONHA markedly reduced the proliferation rate to less than $20 \%$. ONHA and TMC treated with minocycline and TGF $\beta-2$ showed similar results to those of ONHA and TMC treated with minocycline only (data not shown).

\section{Viability assay}

The viability of primary ONHA was tested by labeling the nuclei of nonviable cells with propidium iodide 48 hours after treatment of the cells. For ONHA, minocycline concentrations $1-75 \mu \mathrm{M}$ did not show any significant effect on cell viability (data not shown). If primary ONHA were treated with minocycline concentrations for 48 hours and additionally treated with $600 \mu \mathrm{M} \mathrm{H}_{2} \mathrm{O}_{2}$ for four hours, minocycline concentrations of $20 \mu \mathrm{M}(P<0.001)$ led to a significant increase in viability compared with the control treated with $600 \mu \mathrm{M} \mathrm{H}_{2} \mathrm{O}_{2}$ only (Figure 4N). By contrast, minocycline concentrations of $75 \mu \mathrm{M}$ and higher induced a marked reduction of viable ONHA cells in a dose-dependent manner (Figure 4A-N). TMC (Figure 4O) showed results similar to those of primary ONHA cells.

\section{Expression of $\mathrm{Bcl}-2, \mathrm{XIAP}$, and survivin mRNA in ONHA and TMC}

ONHA and TMC from four donors were used to investigate mRNA expression of Bcl-2, XIAP, and survivin. Bcl-2, 


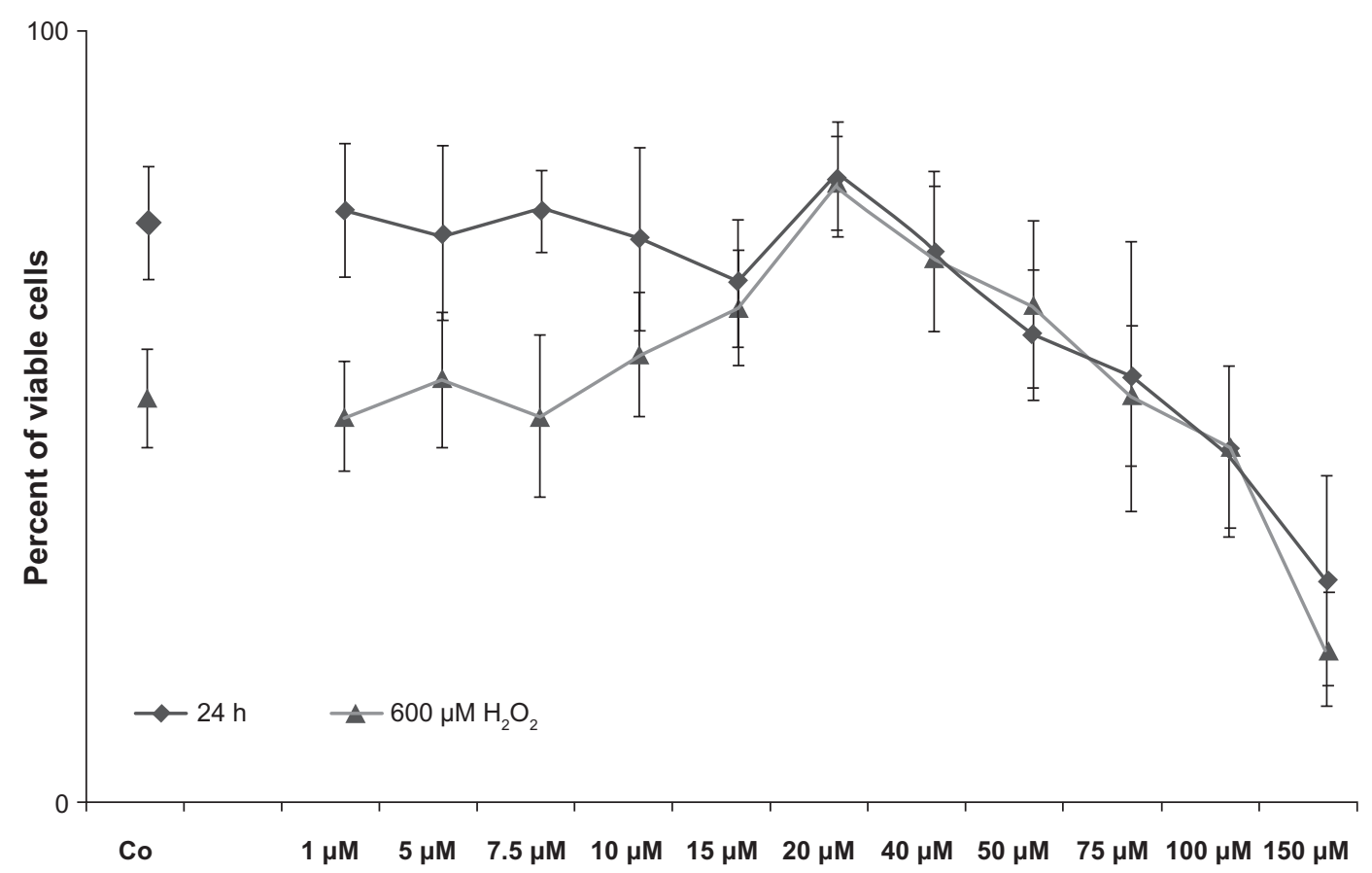

Figure 2 Viability of primary ONHA cells after treatment with the investigated concentrations of minocycline (black curve, diamond) and additionally treated with $600 \mu \mathrm{M}$ $\mathrm{H}_{2} \mathrm{O}_{2}$ (grey curve, triangles), measured by a colorimetric test (MTT). Tests were performed in triplicate and repeated three times. Untreated primary ONHA of the same passage served as the control. Results are expressed as the mean percentage of control cell survival. The data are the mean of results of three experiments, each performed in triplicate. Cells treated only with minocycline concentrations up to $40 \mu \mathrm{M}$ showed no reduction in viability compared with the control, while $50 \mu \mathrm{M}$ and higher showed a significantly reduced viability $(P<0.00 \mathrm{I})$. When cells were treated additionally with $\mathrm{H}_{2} \mathrm{O}_{2}$, those pretreated with minocycline $>\mathrm{I} 5 \mu \mathrm{M}(P=0.02)$ up to $50 \mu \mathrm{M}(P=0.0 \mathrm{I})$ showed a significantly increased viability, with a peak at $20 \mu \mathrm{M}(P<0.00 \mathrm{I})$ compared with the control. Only concentrations as high as I50 $\mu \mathrm{M}$ showed significantly decreased viability $(P<0.001)$. Error bars, \pm SD.

Abbreviations: ONHA; optic nerve head astrocytes; SD, standard deviation.

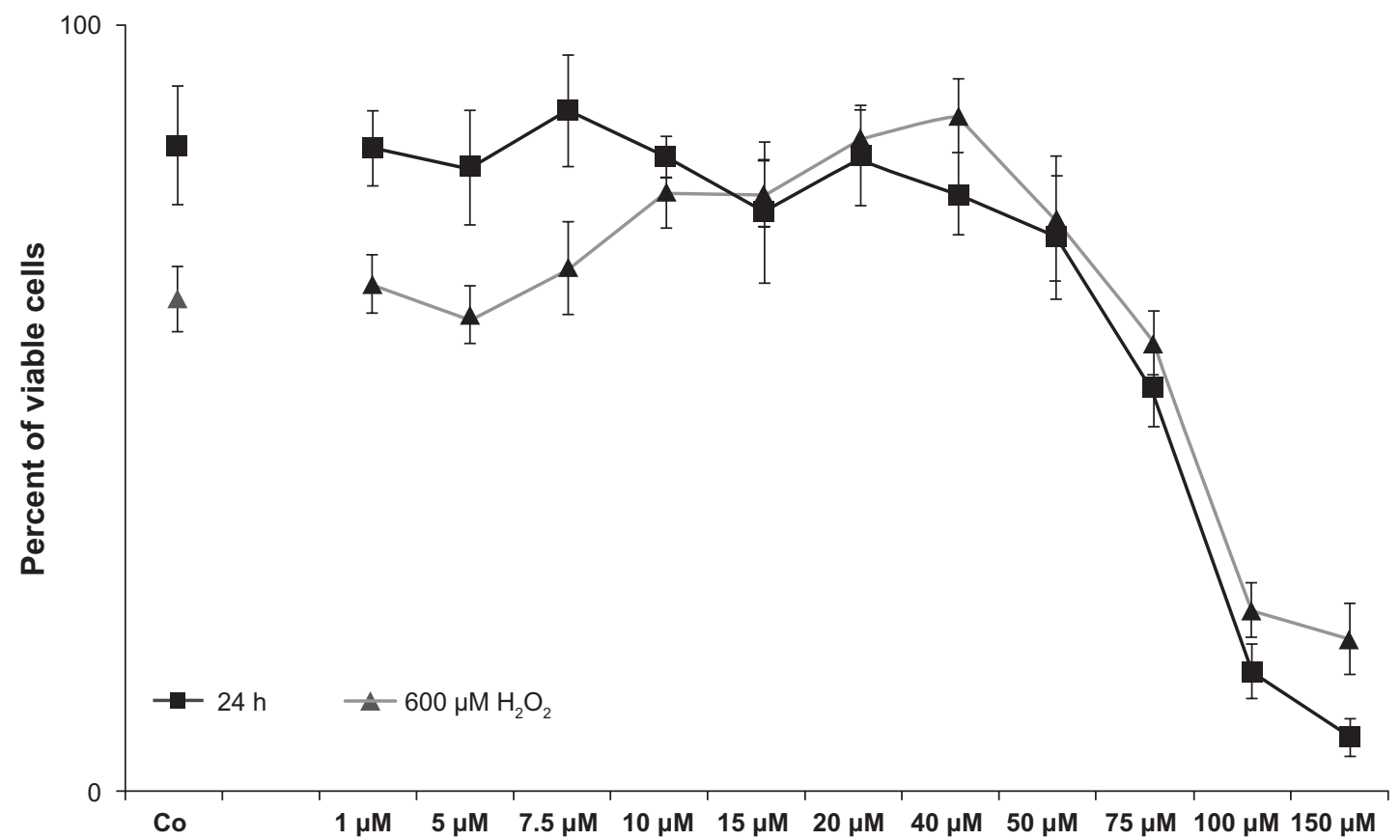

Figure 3 Viability of primary TMC after treatment with the investigated concentrations of minocycline (black curve, squares) and additionally treated with $600 \mu M \mathrm{H}_{2} \mathrm{O}_{2}$ (grey curve, triangles), measured by MTT assay. TMC treated only with minocycline concentrations up to $40 \mu \mathrm{M}$ showed no reduction in viability compared with the control. Minocycline $50 \mu \mathrm{M}(P=0.005)$ and higher for primary TMC led to a dose-dependent reduction of viability. When TMC cells were treated additionally with $\mathrm{H}_{2} \mathrm{O}_{2}$, those pretreated with minocycline $>7.5 \mu \mathrm{M}(P<0.00 \mathrm{I})$ up to $50 \mu \mathrm{M}(P=0.002)$ showed significantly increased viability, with a peak at $40 \mu \mathrm{M}(P<0.00 \mathrm{I})$ compared with the control. Concentrations of $75 \mu \mathrm{M}(P=0.0 \mathrm{I})$ and higher showed a significantly decreased viability. Error bars, $\pm \mathrm{SD}$.

Abbreviations: TMC, trabecular meshwork cells; SD, standard deviation. 


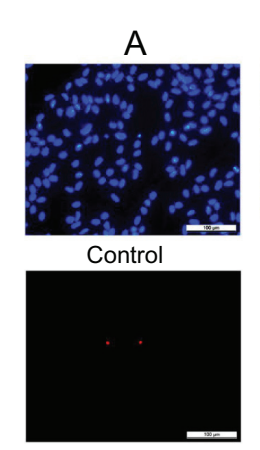

B

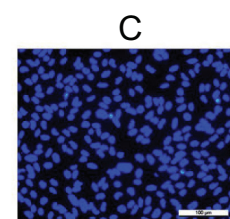

M $20 \mu \mathrm{M}$

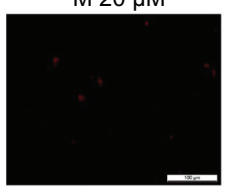

D

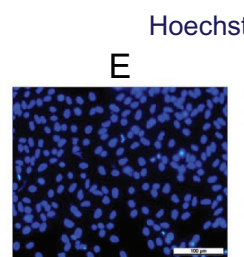

$\mathrm{M} 40 \mu \mathrm{M}$

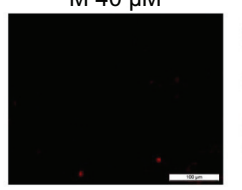

F
G

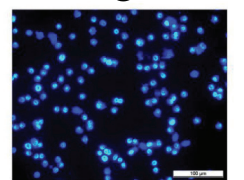

Control $+\mathrm{H}_{2} \mathrm{O}_{2}$

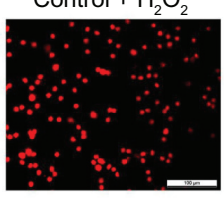

$\mathrm{H}$

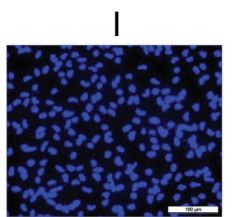

$\mathrm{M} 2 \mathrm{O} \mu \mathrm{M}+\mathrm{H}_{2} \mathrm{O}_{2}$

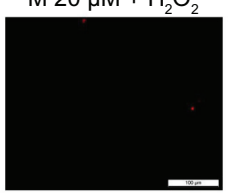

K

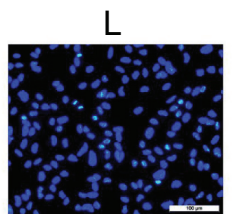

$\mathrm{M} 40 \mu \mathrm{M}+\mathrm{H}_{2} \mathrm{O}$

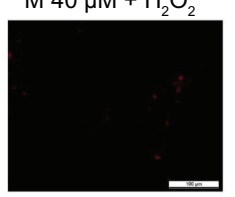

M
N

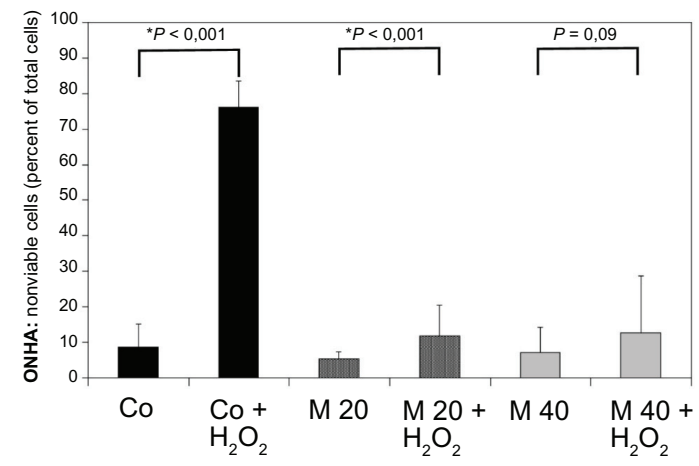

$\mathrm{O}$

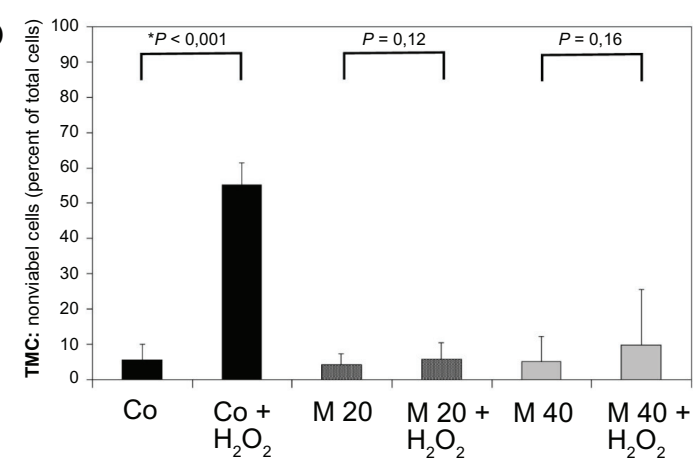

Figure 4 Primary ONHA and TMC were treated for 48 hours with various concentrations of minocycline only or additionally treated with $600 \mu \mathrm{M} \mathrm{H}_{2} \mathrm{O}_{2}$ for four hours. After exposure of the cells to the substance alone and in combination with oxidative stress, viability was determined by staining all nuclei with Hoechst 33342 and dead cells with propidium iodide. (A) Representative fluorescence photomicrograph of Hoechst 33342-stained, untreated ONHA as control. (B) Nonviable cells in the corresponding field. Fluorescence photomicrograph of ONHA treated with minocycline $20 \mu \mathrm{M}$ (C) and $40 \mu \mathrm{M}$ (E) for 48 hours and labeled with Hoechst 33342. Nonviable ONHA treated

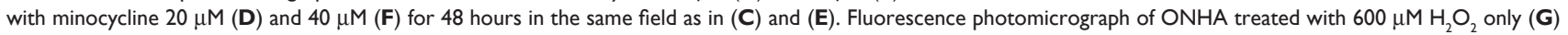
and with minocycline $20 \mu \mathrm{M}(\mathbf{I})$ and $40 \mu \mathrm{M}(\mathbf{L})$ for 48 hours and additionally treated with $600 \mu \mathrm{M} \mathrm{H}_{2} \mathrm{O}_{2}$ and labelled with Hoechst 33342. Nonviable ONHA treated with $600 \mu \mathrm{M} \mathrm{H}_{2} \mathrm{O}_{2}$ only $(\mathbf{H})$ and with minocycline $20 \mu \mathrm{M}(\mathbf{K})$ and $40 \mu \mathrm{M}(\mathbf{M})$ for 48 hours and additionally treated with $600 \mu \mathrm{M} \mathrm{H}_{2} \mathrm{O}_{2}$ in the same field as in (G, I, L). TMC yielded a similar result (data not shown). Quantification of effect of minocycline treatment alone and additional treatment with $\mathrm{H}_{2} \mathrm{O}_{2}$ on numbers of nonviable primary ONHA (N) and TMC (O). The percentage of dead cells was scored by counting at least 500 cells in fluorescence photomicrographs of representative fields. Data (mean \pm SD) are based on the sampling of 6-10 photomicrographs per condition in three independent experiments performed in duplicate. Comparison with controls is shown above the bars with significant differences marked by an asterisk.

Abbreviations: TMC, trabecular meshwork cells; ONHA; optic nerve head astrocytes; SD, standard deviation.

XIAP, and survivin mRNA expression were detectable in every sample. All detected mRNA levels of Bcl-2, XIAP, and survivin were normalized to those of $18 \mathrm{~S}$ rRNA, and the values are expressed as the relative ratio of $\mathrm{Bcl}-2 / 18 \mathrm{~S}$, XIAP/18S, or survivin/18S.

Our findings indicate that treatment with minocycline leads to increased mRNA expression for both investigated cell lines for all three tested antiapoptotic proteins. In contrast, TGF $\beta-2$ and $\mathrm{H}_{2} \mathrm{O}_{2}$ treatment decreased mRNA expression of Bcl-2, XIAP, and survivin in both ONHA and TMC (Figures 5,6 , and 7). Cells treated with minocycline and with TGF $\beta-2$ or $\mathrm{H}_{2} \mathrm{O}_{2}$ seemed to compensate for the detected decrease of Bcl-2, XIAP, and survivin mRNA expression. Minocyclinetreated cells reached mRNA levels of Bcl-2, XIAP, and survivin comparable with those of the untreated control, or even higher. In addition, cells pretreated with minocycline and then treated with TGF $\beta-2$ or $\mathrm{H}_{2} \mathrm{O}_{2}$ showed significantly higher levels of Bcl-2, XIAP, and survivin mRNA in ONHA and TMC than cells treated only with TGF $\beta-2$ or $\mathrm{H}_{2} \mathrm{O}_{2}$. These effects were found for both ONHA and TMC when cells were treated with minocycline concentrations of $20 \mu \mathrm{M}$ and $40 \mu \mathrm{M}$ (Figures 5, 6, and 7). When cells were treated with minocycline concentrations less than $10 \mu \mathrm{M}$, the described effects decreased and did not reach statistical significance (data not shown).

\section{Protein expression of $\mathrm{Bcl}-2, \mathrm{XIAP}$, and survivin in ONHA and TMC}

To verify that the increase in mRNA transcription of Bcl-2, XIAP, and survivin by minocycline translates into increased protein synthesis, whole cellular protein extracts of untreated control cells, cells treated with minocycline alone, and cells treated with minocycline and then with TGF $\beta$ - 2 or $600 \mu \mathrm{M} \mathrm{H}_{2} \mathrm{O}_{2}$, were analyzed by Western blotting. When cells were treated with $600 \mu \mathrm{M} \mathrm{H}_{2} \mathrm{O}_{2}, \mathrm{Bcl}-2$ expression decreased 10-fold in ONHA and twofold in 
ONHA: RNA expression of Bcl-2
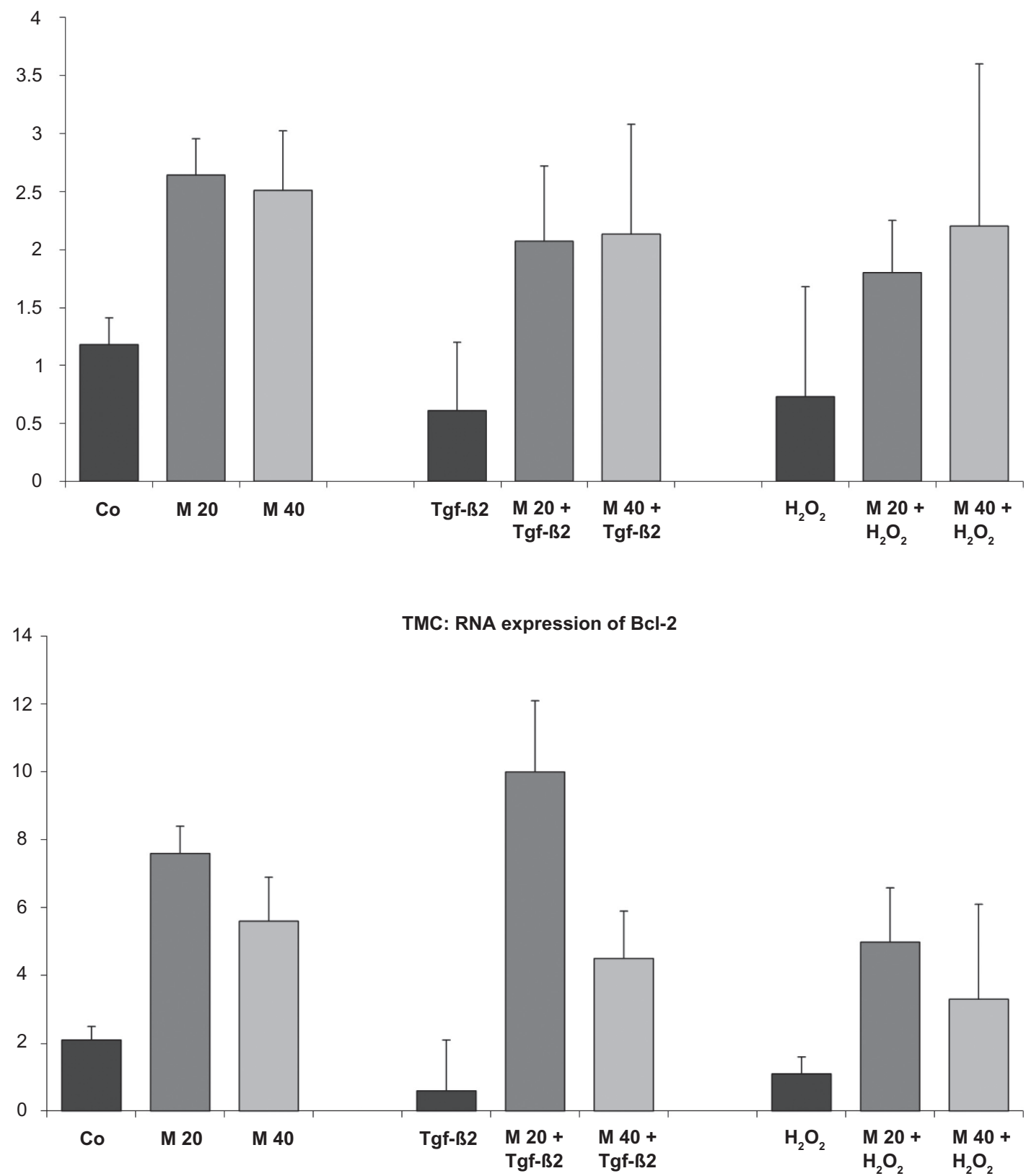

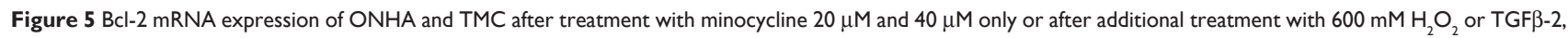
as investigated by quantitative RT-PCR. All tests were performed in triplicate and repeated three times. The mRNA levels were normalized to those of I8S rRNA and expressed as the ratio of $\mathrm{Bcl}-2 \mathrm{mRNA} / \mathrm{ISS}$ rRNA. ONHA treated with minocycline concentrations showed a significant increase in Bcl-2 mRNA expression compared with the control in both cell lines. TGF $\beta-2$ and $\mathrm{H}_{2} \mathrm{O}_{2}$ treatment decreased Bcl-2 expression. When ONHA cells were treated with minocycline $20 \mu \mathrm{M}$ and $40 \mu \mathrm{M}$ and TGF $\beta-2$ or $\mathrm{H}_{2} \mathrm{O}_{2}$, Bcl-2 expression was increased compared with ONHA treated only with TGF $\beta-2$ or $\mathrm{H}_{2} \mathrm{O}_{2}$. Similarly, TMC treated with minocycline $20 \mu M$ and TGF 3 -2 or $\mathrm{H}_{2} \mathrm{O}_{2}$ showed an increased expression of $\mathrm{Bcl}-2$ mRNA compared with TMC treated only with TGF $\beta-2$ or $\mathrm{H}_{2} \mathrm{O}_{2}$. All differences between the two minocycline concentrations and the corresponding controls are statistically significant.

Key: $x$-axis, RR of Bcl-2 mRNA normalized to 18s rRNA expressed in decimal format; $y$-axis, tested concentrations of minocycline.

Abbreviations: TMC, trabecular meshwork cells; ONHA; optic nerve head astrocytes; RT-PCR, real time polymerase chain reaction; RR, relative ratio; TGF $\beta-2$, transforming growth factor-beta-2.

TMC compared with the control (Figure 8). TGF $\beta-2$ treatment $(1 \mathrm{ng} / \mathrm{mL})$ decreased Bcl-2 expression by approximately 2.5 -fold in ONHA and by twofold in TMC. Treatment with minocycline alone did not increase protein expression of Bcl-2 or XIAP in primary human ONHA or
TMC. Compared with cells treated only with $\mathrm{H}_{2} \mathrm{O}_{2}$, cells pretreated with $20 \mu \mathrm{M}$ minocycline and then with $\mathrm{H}_{2} \mathrm{O}_{2}$ showed a significantly lower decrease of Bcl-2 of approximately 1.5-fold in ONHA cells and a 1.25-fold increase in TMC and a significant increase of 7.5 -fold in ONHA 
ONHA: RNA expression of XIAP
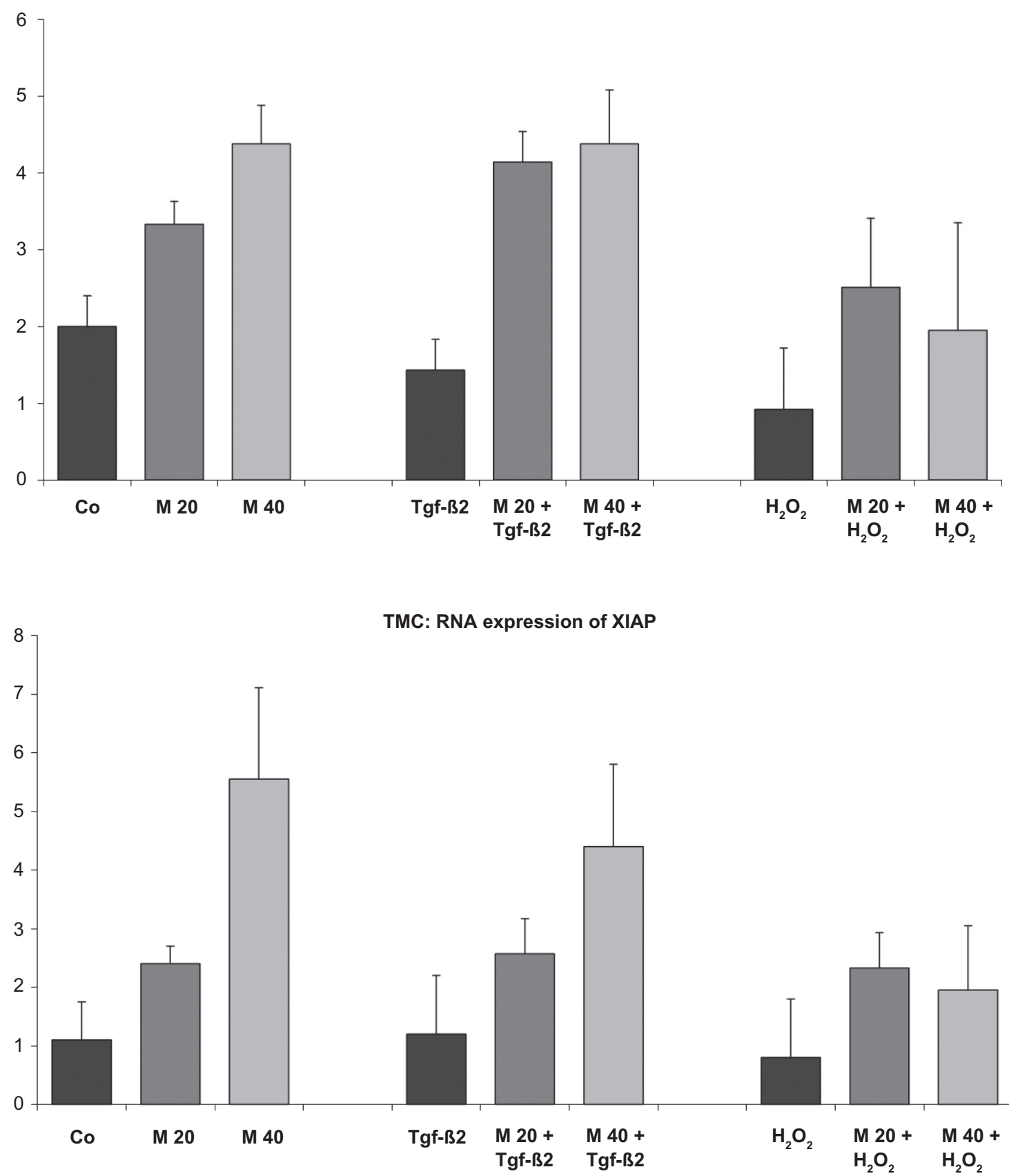

Figure 6 XIAP mRNA expression of ONHA and TMC after treatment with minocycline only and after additional treatment with $\mathrm{H}_{2} \mathrm{O}_{2}$ or TGF $\beta-2$. ONHA treated with 40 minocycline $\mu \mathrm{M}$ showed a significant increase in XIAP mRNA expression compared with the control in both cell lines. TGF $\beta-2$ and $\mathrm{H}_{2} \mathrm{O}_{2}$ treatment slightly decreased XIAP expression in ONHA and treatment with minocycline $20 \mu \mathrm{M}$ and $40 \mu \mathrm{M}$ and TGF $\beta-2$ or $\mathrm{H}_{2} \mathrm{O}_{2}$ increased expression of XIAP compared with ONHA treated only with TGF $\beta-2$ or $\mathrm{H}_{2} \mathrm{O}_{2}$. TMC treated with minocyline $20 \mu \mathrm{M}$ and TGF $\beta-2$ or $\mathrm{H}_{2} \mathrm{O}_{2}$ showed an increased expression of XIAP mRNA compared with TMC treated only with TGF $\beta-2$ or $\mathrm{H}_{2} \mathrm{O}_{2}$. All differences between the two minocycline concentrations and the corresponding controls are statistically significant.

Key: $x$-axis, RR of XIAP mRNA normalized to 18s rRNA expressed in decimal format; $y$-axis, tested concentrations of minocycline.

Abbreviations: TMC, trabecular meshwork cells; ONHA; optic nerve head astrocytes; RR, relative ratio; TGF $\beta$-2, transforming growth factor-beta-2.

cells and twofold in TMC. When cells were treated with 20 $\mu \mathrm{M}$ minocycline and TGF $\beta-2, \mathrm{Bcl}-2$ expression increased by approximately twofold in ONHA cells and by 1.5 -fold in TMC cells, compared with cells treated with TGF $\beta-2$ only. The decrease of Bcl-2 compared with the untreated control was 1.5-fold in ONHA cells and two-fold in TMC cells, which was significantly lower than the decrease after TGF $\beta$-2 treatment only (Figure 8).

The XIAP expression decreased 2.5-fold in ONHA cells and fivefold in TMC cells treated with $600 \mu \mathrm{M} \mathrm{H}_{2} \mathrm{O}_{2}$ 


\section{ONHA: RNA expression of survivin}
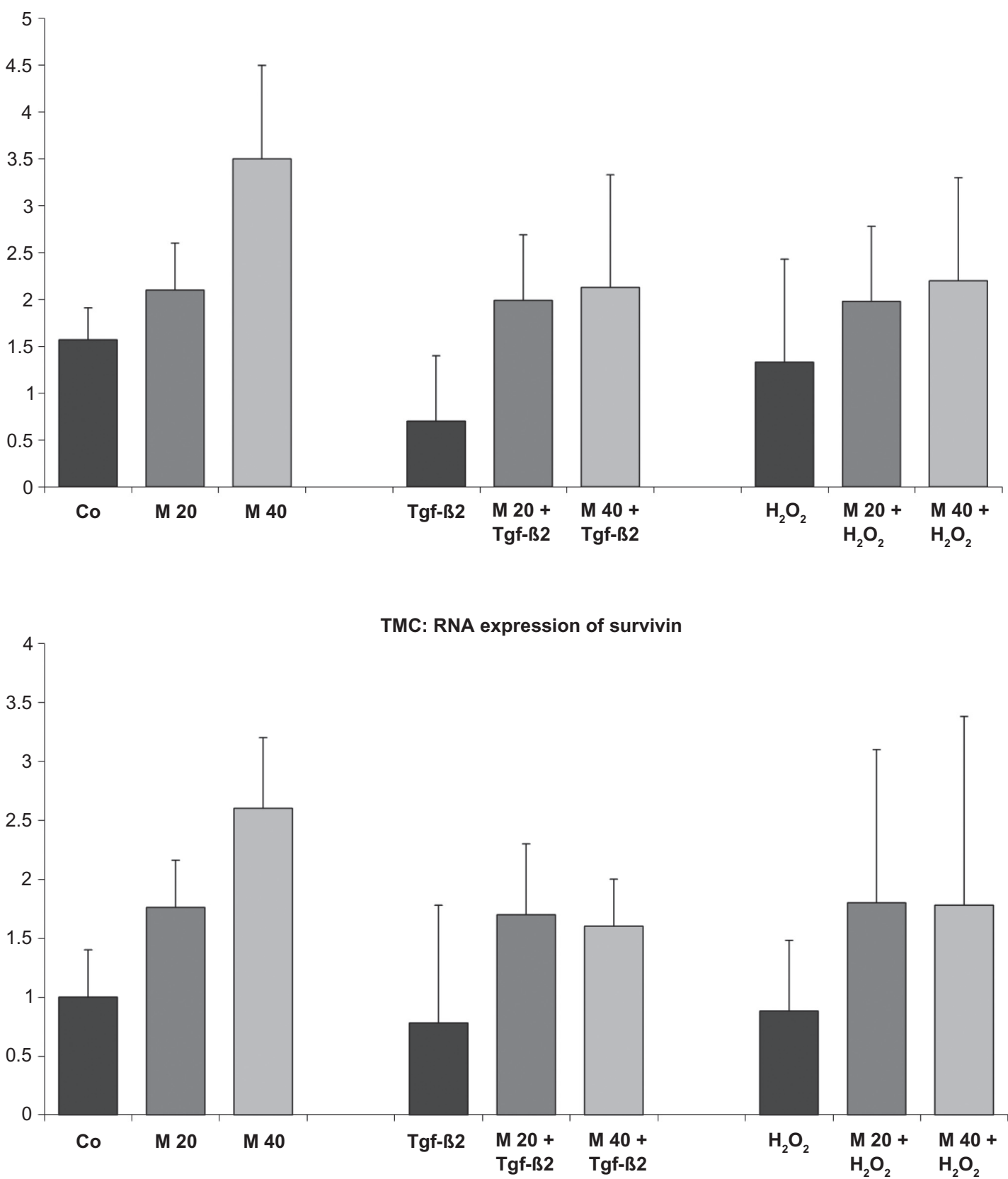

Figure 7 Survivin mRNA expression measured by quantitative RT-PCR. ONHA treated with minocycline $40 \mu \mathrm{M}$ showed a significant increase in survivin mRNA expression compared with the control. TMC showed this increase for minocycline $20 \mu \mathrm{M}$ and $40 \mu \mathrm{M}$. TGF $\beta-2$ decreased survivin expression, and $\mathrm{H}_{2} \mathrm{O}_{2}$ treatment slightly decreased survivin expression for both cell lines. Treatment with minocycline $20 \mu \mathrm{M}$ and $40 \mu \mathrm{M}$ and additional treatment with TGF $\beta-2$ increased expression of survivin compared with cells treated only with TGF $\beta$-2. For cells treated additionally with $\mathrm{H}_{2} \mathrm{O}_{2}$, ONHA cells only showed a slight increase and TMC cells showed a more pronounced increase when pretreated with minocycline concentrations compared with cells treated with $\mathrm{H}_{2} \mathrm{O}_{2}$ only. All differences between the two minocycline concentrations and the corresponding controls are statistically significant except for the $\mathrm{H}_{2} \mathrm{O}_{2}$ group with ONHA.

Abbreviations: TMC, trabecular meshwork cells; ONHA; optic nerve head astrocytes; RT-PCR, real time polymerase chain reaction; TGF $\beta$-2, transforming growth factor-beta-2.

(Figure 9). TGF $\beta$-2 decreased XIAP expression 10-fold in ONHA cells and twofold in TMC cells, compared with the control. Cells pretreated with $20 \mu \mathrm{M}$ minocycline and then with $\mathrm{H}_{2} \mathrm{O}_{2}$ showed a significantly lower decrease of XIAP expression of 1.5-fold in ONHA cells and 1.25-fold in TMC cells than those cells that were treated with $\mathrm{H}_{2} \mathrm{O}_{2}$ only $(2.5 \times)($ TMC $5 \times)$. The same effect could be detected for TGF $\beta-2$ treatment, whereby ONHA and TMC cells pretreated with minocycline $20 \mu \mathrm{M}$ showed no decrease in XIAP expression compared with the control, but cells treated with 


\section{Expression of $\mathrm{Bcl}-2$}

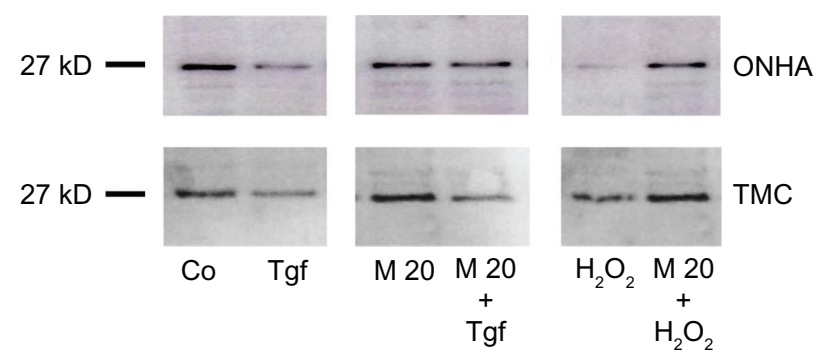

Figure 8 Effect of minocycline treatment on $\mathrm{Bcl}-2$ protein expression. ONHA and TMC were treated with minocycline $20 \mu \mathrm{M}$ only or additionally with TGF $\beta-2$ ( I ng/mL) or $600 \mu \mathrm{M} \mathrm{H}_{2} \mathrm{O}_{2}$. Western blotting was used to analyze protein expression in control (Co) and treated cell extracts: TGF $\beta-2$ (Tgf), $20 \mu \mathrm{M}$ minocycline (M20), minocycline $20 \mu \mathrm{M}$ and TGF $\beta-2$ (M20+Tgf), $600 \mu \mathrm{M} \mathrm{H} \mathrm{H}_{2} \mathrm{O}_{2}\left(\mathrm{H}_{2} \mathrm{O}_{2}\right)$, and minocycline $20 \mu \mathrm{M}$ and $600 \mu \mathrm{M} \mathrm{H}_{2} \mathrm{O}_{2}\left(\mathrm{M} 20+\mathrm{H}_{2} \mathrm{O}_{2}\right)$. Ten micrograms of protein was loaded per lane.

Abbreviations: TMC, trabecular meshwork cells; ONHA; optic nerve head astrocytes; TGF $\beta-2$, transforming growth factor-beta-2.

TGF $\beta$ - 2 only did show a 10-fold decrease in XIAP expression in ONHA cells and a twofold decrease in expression in TMC cells (Figure 9).

Survivin expression in ONHA decreased fivefold in ONHA cells and 2.5-fold in TMC cells treated with $600 \mu \mathrm{M} \mathrm{H}_{2} \mathrm{O}_{2}$ (Figure 10). TGF $\beta$-2 decreased XIAP expression by 2.5 -fold in ONHA cells and by twofold in TMC compared with the control. When ONHA cells were treated with minocycline $20 \mu \mathrm{M}$, a 2.5-fold increase in survivin expression was detected in ONHA cells but not for TMC cells. ONHA cells pretreated with minocycline $20 \mu \mathrm{M}$ and then with $\mathrm{H}_{2} \mathrm{O}_{2} 600 \mu \mathrm{M}$ showed a slight increase of survivin expression of 1.1-fold in ONHA cells, while TMC cells showed a decrease of twofold compared with the control. By contrast, cells treated only with $\mathrm{H}_{2} \mathrm{O}_{2}$ showed a fivefold decrease in survivin expression in ONHA cells and a 2.5-fold decrease in TMC cells.

\section{Expression of XIAP}

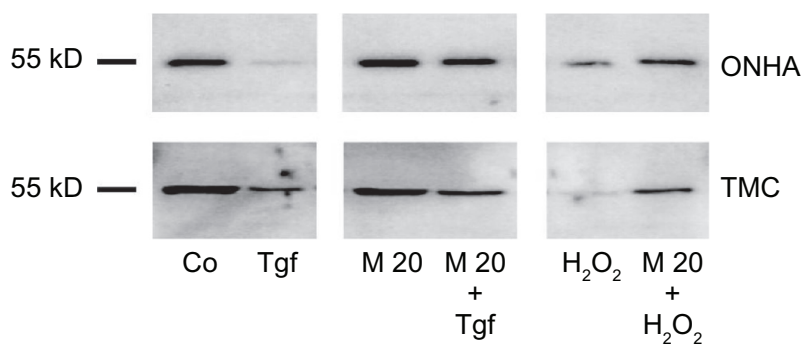

Figure 9 Expression of XIAP. Western blot showing the protein expression of XIAP in control (Co) and treated cell extracts: TGF $\beta-2$ (Tgf), minocycline $20 \mu \mathrm{M}(\mathrm{M} 20)$, minocycline $20 \mu \mathrm{M}$ and TGF $\beta$-2 (M20+Tgf), $600 \mu \mathrm{M} \mathrm{H} \mathrm{H}_{2} \mathrm{O}_{2}\left(\mathrm{H}_{2} \mathrm{O}_{2}\right)$, and treatment with minocycline $20 \mu \mathrm{M}$ and $600 \mu \mathrm{M} \mathrm{H}_{2} \mathrm{O}_{2}\left(\mathrm{M} 2 \mathrm{O}+\mathrm{H}_{2} \mathrm{O}_{2}\right)$. Ten micrograms of protein were loaded per lane.

Abbreviations: TMC, trabecular meshwork cells; ONHA; optic nerve head astrocytes; TGF $\beta-2$, transforming growth factor-beta-2.

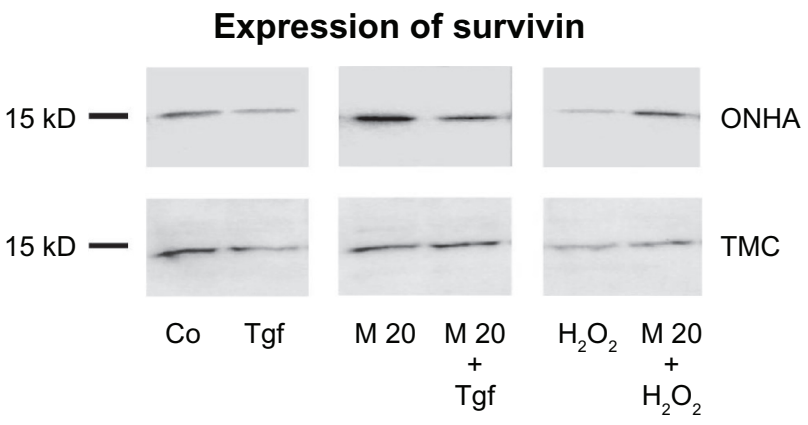

Figure 10 Expression of survivin. Western blot showing the protein expression of survivin in control (Co) and treated cell extracts: TGF $\beta-2$ (Tgf), minocycline

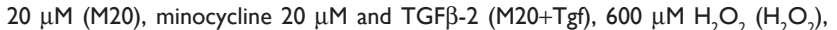
and minocycline $20 \mu \mathrm{M}$ and $600 \mu \mathrm{M} \mathrm{H}_{2} \mathrm{O}_{2}\left(\mathrm{M} 20+\mathrm{H}_{2} \mathrm{O}_{2}\right)$. Ten micrograms of protein were loaded per lane.

Abbreviations: TMC, trabecular meshwork cells; ONHA; optic nerve head astrocytes; TGF $\beta-2$, transforming growth factor-beta-2.

ONHA cells pretreated with minocycline $20 \mu \mathrm{M}$ and then treated with TGF $\beta-2$ showed a 1.5-fold increase in survivin expression compared with the control, which was a 3.5-fold higher survivin expression compared with cells treated with TGF $\beta$-2 only. TMC cells pretreated with minocycline $20 \mu \mathrm{M}$ showed a lower decrease of survivin expression of 1.25-fold than cells treated with TGF $\beta$-2 only (twofold, see Figure 10).

\section{Discussion}

Glaucomatous loss of visual field is mainly due to RGC death and neuronal degeneration, and there is evidence that these cells mainly die as a result of apoptosis. ${ }^{19-22}$ IOP elevation and visual field damage have been shown to be proportional to oxidative damage in the human TM. ${ }^{16}$ Cell loss, altered functionality, and a decrease in the outflow facility of the TM have been suggested as a result of oxidative damage in the TM. ${ }^{47,48}$ In addition, a significantly decreased TM cellularity, especially in the filtering area of the TM, is found in patients suffering from glaucoma, compared with age-matched nonglaucomatous subjects. ${ }^{9}$ Recent data suggest that these structural changes in the TM and a decrease in TMC, which leads to elevated IOP, are also triggered by apoptosis, ${ }^{10,23,24}$ so antiapoptotic and neuroprotective agents could support and complement the proven but incomplete therapeutic effect of decreasing IOP. Our findings demonstrate that minocycline effectively protects primary human $\mathrm{TMC}$ and $\mathrm{ONHA}$ in vitro against oxidative stress and induces a marked reduction in cellular death. We were able to show that this protection is associated with the induction of three antiapoptotic proteins, ie, Bcl-2, XIAP, and survivin. These three proteins are known inhibitors of major pathways of apoptosis. 
Apoptosis is a mechanism that is genetically controlled by the dying cell, resulting in the activation of tumor suppressor proteins ${ }^{49}$ and apoptosis-initiating caspases. ${ }^{50}$ One mechanism in the cell death program is upregulation of the proapoptotic Bax protein. This increase in Bax expression effects a change in the permeability of mitochondrial membranes. That leads to the release of cytochrome $\mathrm{c}$ and the activation of caspases, which finally proteolyze cellular components. ${ }^{51} \mathrm{Bcl}-2$ is one of the key genes known to downregulate Bax and p53, and therefore has the potency to inhibit this apoptotic pathway. ${ }^{52,53}$ Therefore, pharmacologic upregulation of $\mathrm{Bcl}-2$ is a highly interesting approach to inhibition of apoptosis.

XIAP and survivin are members of a group of proteins called inhibitors of apoptosis (IAPs). ${ }^{54-56}$ XIAP inhibits apoptosis by directly blocking the activity of the terminal effector cell death proteases, caspases 3, 7, and 9. It has been demonstrated in vivo that overexpression of XIAP protects injured neuronal cells and photoreceptors from further compromise. ${ }^{57,58}$ Survivin interacts with $\mathrm{p} 21^{59}$ and thus suppresses Fas-mediated cell death. ${ }^{60}$ Its antiapoptotic effects seem to result from its ability to block caspases 3 and 7. In addition, survivin prevents cells from responding to apoptotic stimuli. ${ }^{61} \mathrm{Bcl}-2$, XIAP, and survivin, all show antiapoptotic effects. Because minocycline upregulates RNA levels of Bcl-2, XIAP, and survivin in ONHA and TMC, it has high antiapoptotic potency on those cell lines.

There is evidence that both oxidative stress and elevated levels of TGF $\beta$-2 support the development and progression of glaucoma. ${ }^{16-18,62,63}$ For this reason, the present study investigated TGF $\beta-2$, the isoform of TGF $\beta$ that is expressed most in human eyes. Recent studies have shown that elevated levels of TGF $\beta$, especially TGF $\beta$ - 2 , are found in glaucomatous eyes and seem to have a major influence on the pathogenesis of glaucoma. ${ }^{17,18}$ So another important finding of our study is that TGF $\beta-2$ downregulates both mRNA levels and protein expression of Bcl-2, XIAP, and survivin in primary human ONHA and TMC. In contrast, minocycline protects both cell lines against TGF $\beta$-2-induced downregulation of these three antiapoptotic proteins and returns levels back to normal or even increases them. We were also able to show that minocycline protects ONHA and TMC against oxidative stress, which is another important pathologic trigger for glaucoma.

Because of its antibiotic and anti-inflammatory actions, minocycline is widely used, and has had proven safety as an oral antibiotic for many years. ${ }^{27,28}$ Because minocycline crosses the blood-brain barrier effectively ${ }^{25}$ and penetrates well into the eye, ${ }^{26}$ the optic nerve and ocular cells are potentially susceptible to oral treatment. Due to the very good bioavailability of minocycline, the tested concentration of $20 \mu \mathrm{M}$ would correspond to an estimated dose of approximately $750 \mathrm{mg} /$ day in adult humans, which is undoubtedly a high dosage. On the other hand, previous reports have shown that daily tetracycline doses even higher than $2000 \mathrm{mg}$ are still relatively safe in healthy pregnant women. ${ }^{27}$ Therefore, it might be worthwhile to investigate the antiapoptotic and cytoprotective effects of minocycline in glaucoma treatment further.

Glaucoma is a chronic disease, and the long-term utilization of antibiotics is known to be associated with side effects. ${ }^{64,65}$ Minocycline seems to be safe even for long-term high-dose treatment ${ }^{66}$ but, in the end, the relatively high dosages needed to achieve the cytoprotective effects described here might limit its application as long term medication. On the other hand, there are situations where acute cell stress is predominant, ie, in cases of acute glaucoma or in end-stage glaucoma patients needing glaucoma-filtering surgery, where the risk of "wipeout" (loss of the central visual field) is feared. ${ }^{67,68}$ In such cases, minocycline might offer a new option to protect affected eyes from further damage.

Our results demonstrate the cytoprotective effects of minocycline on primary human ONHA and TMC. These in vitro data cannot be automatically extrapolated to an in vivo situation. Even high doses of minocycline are tolerated well in vivo ${ }^{27,66}$ but it is not clear if this cytoprotective action of minocycline is effective in the long term and whether it is actually possible to reach therapeutic concentrations inside the eye. Further investigations are therefore needed on these points. Certainly further basic and clinical studies are needed, but the present study makes an early contribution towards shedding light on the potential protective effects of minocycline and to find possible new treatment strategies for glaucoma.

\section{Acknowledgments}

The authors thank Katja Obholzer for providing excellent technical assistance.

\section{Disclosure}

The authors do not have any commercial interest in any of the materials used in this study.

\section{References}

1. Van Buskirk EM, Cioffi GA. Glaucomatous optic neuropathy. Am J Ophthalmol. 1992;113:447-452.

2. World Health Organization. Magnitude and causes of visual impairment. Fact Sheet Number 282: World Health Organization; 2004. Available at: http://www.who.int/mediacentre/factsheets/fs282/en/. Accessed May 12, 2010. 
3. Quigley HA, Green WR. The histology of human glaucoma cupping and optic nerve damage: Clinicopathologic correlation in 21 eyes. Ophthalmology. 1979;86:1803-1830.

4. Goldberg LD. Clinical guidelines for the treatment of glaucoma. Manag Care. 2002;11:16-24.

5. Kass MA, Heuer DK, Higginbotham EJ, et al. The Ocular Hypertension Treatment Study: A randomized trial determines that topical ocular hypotensive medication delays or prevents the onset of primary open-angle glaucoma. Arch Ophthalmol. 2002;120:701-13; discussion 829-830.

6. Heijl A, Leske MC, Bengtsson B, Hyman L, Hussein M. Reduction of intraocular pressure and glaucoma progression: Results from the Early Manifest Glaucoma Trial. Arch Ophthalmol. 2002;120:1268-1279.

7. Krakau CE. Intraocular pressure elevation - cause or effect in chronic glaucoma? Ophthalmologica. 1981;182:141-147.

8. Bonomi L, Marchini G, Marraffa M, Morbio R. The relationship between intraocular pressure and glaucoma in a defined population. Data from the Egna-Neumarkt Glaucoma Study. Ophthalmologica. 2001;215:34-38.

9. Alvarado J, Murphy C, Juster R. Trabecular meshwork cellularity in primary open-angle glaucoma and nonglaucomatous normals. Ophthalmology. 1984;91:564-579.

10. Rohen JW, Lutjen-Drecoll E, Flugel C, Meyer M, Grierson I. Ultrastructure of the trabecular meshwork in untreated cases of primary open-angle glaucoma (POAG). Exp Eye Res. 1993;56: 683-692.

11. Veach J. Functional dichotomy: Glutathione and vitamin E in homeostasis relevant to primary open-angle glaucoma. Br J Nutr. 2004;91 809-829.

12. Findl O, Rainer G, Dallinger S, et al. Assessment of optic disk blood flow in patients with open-angle glaucoma. Am J Ophthalmol. 2000; 130:589-596.

13. Butt Z, O’Brien C, McKillop G, Aspinall P, Allan P. Color Doppler imaging in untreated high- and normal-pressure open-angle glaucoma Invest Ophthalmol Vis Sci. 1997;38:690-696.

14. Ferreira SM, Lerner SF, Brunzini R, Evelson PA, Llesuy SF. Oxidative stress markers in aqueous humor of glaucoma patients. $\mathrm{Am}$ J Ophthalmol. 2004;137:62-69.

15. Levin LA, Clark JA, Johns LK. Effect of lipid peroxidation inhibition on retinal ganglion cell death. Invest Ophthalmol Vis Sci. 1996;37: 2744-2749.

16. Sacca SC, Pascotto A, Camicione P, Capris P, Izzotti A. Oxidative DNA damage in the human trabecular meshwork: Clinical correlation in patients with primary open-angle glaucoma. Arch Ophthalmol. 2005;123:458-463.

17. Fleenor DL, Shepard AR, Hellberg PE, Jacobson N, Pang IH, Clark AF. TGFbeta2-induced changes in human trabecular meshwork: Implications for intraocular pressure. Invest Ophthalmol Vis Sci. 2006;47: 226-234.

18. Min SH, Lee TI, Chung YS, Kim HK. Transforming growth factor-beta levels in human aqueous humor of glaucomatous, diabetic and uveitic eyes. Korean J Ophthalmol. 2006;20:162-165.

19. Nickells RW. Apoptosis of retinal ganglion cells in glaucoma: An update of the molecular pathways involved in cell death. Surv Ophthalmol. 1999;43 Suppl 1:S151-S161.

20. Garcia-Valenzuela E, Shareef S, Walsh J, Sharma SC. Programmed cell death of retinal ganglion cells during experimental glaucoma. Exp Eye Res. 1995;61:33-44.

21. Kerrigan LA, Zack DJ, Quigley HA, Smith SD, Pease ME. TUNELpositive ganglion cells in human primary open-angle glaucoma. Arch Ophthalmol. 1997;115:1031-1035.

22. Quigley HA, Nickells RW, Kerrigan LA, Pease ME, Thibault DJ, Zack DJ. Retinal ganglion cell death in experimental glaucoma and after axotomy occurs by apoptosis. Invest Ophthalmol Vis Sci. 1995;36: 774-786.

23. Cao Y, Wei H, Pfaffl M, Da B, Li Z. Apoptosis of human trabecular meshwork cells induced by transforming growth factor-beta2 in vitro. J Huazhong Univ Sci Technolog Med Sci. 2004;24:87-89, 94.
24. Ziangirova GG, Antonova OV. Lipid peroxidation in the pathogenesis of primary open-angle glaucoma. Vestn Oftalmol. 2003;119:54-55. Russian.

25. Aronson AL. Pharmacotherapeutics of the newer tetracyclines. $J$ Am Vet Med Assoc. 1980;176:1061-1068.

26. Poirier RH, Ellison AC. Ocular penetration of orally administered minocycline. Ann Ophthalmol. 1979;11:1859-1861.

27. Klein NC, Cunha BA. Tetracyclines. Med Clin North Am. 1995;79: 789-801.

28. Ryan ME, Greenwald RA, Golub LM. Potential of tetracyclines to modify cartilage breakdown in osteoarthritis. Curr Opin Rheumatol. 1996;8:238-247.

29. Wirostko E, Wirostko WJ, Wirostko BM. Age-related macular degeneration is an inflammatory disease possibly treatable with minocycline. Acta Ophthalmol Scand. 2004;82:243-244.

30. Chen M, Ona VO, Li M, et al. Minocycline inhibits caspase-1 and caspase-3 expression and delays mortality in a transgenic mouse model of Huntington disease. Nat Med. 2000;6:797-801.

31. Yrjanheikki J, Keinanen R, Pellikka M, Hokfelt T, Koistinaho J. Tetracyclines inhibit microglial activation and are neuroprotective in global brain ischemia. Proc Natl Acad Sci U S A. 1998;95:15769-15774.

32. Zhu S, Stavrovskaya IG, Drozda M, et al. Minocycline inhibits cytochrome $\mathrm{c}$ release and delays progression of amyotrophic lateral sclerosis in mice. Nature. 2002;417:74-78.

33. Sanchez Mejia RO, Ona VO, Li M, Friedlander RM. Minocycline reduces traumatic brain injury-mediated caspase-1 activation, tissue damage, and neurological dysfunction. Neurosurgery. 2001;48:1393-9; discussion 1399-1401.

34. Popovic N, Schubart A, Goetz BD, Zhang SC, Linington C, Duncan ID. Inhibition of autoimmune encephalomyelitis by a tetracycline. Ann Neurol. 2002;51:215-223.

35. Du Y, Ma Z, Lin S, et a1. Minocycline prevents nigrostriatal dopaminergic neurodegeneration in the MPTP model of Parkinson's disease. Proc Natl Acad Sci U S A. 2001;98: 14669-14674.

36. Kraus RL, Pasieczny R, Lariosa-Willingham K, Turner MS, Jiang A, Trauger JW. Antioxidant properties of minocycline: Neuroprotection in an oxidative stress assay and direct radical-scavenging activity. J Neurochem. 2005;94:819-827.

37. Tikka T, Fiebich BL, Goldsteins G, Keinanen R, Koistinaho J. Minocycline, a tetracycline derivative, is neuroprotective against excitotoxicity by inhibiting activation and proliferation of microglia. $J$ Neurosci. 2001;21:2580-2588.

38. Wang J, Wei Q, Wang CY, Hill WD, Hess DC, Dong Z. Minocycline up-regulates Bcl-2 and protects against cell death in mitochondria. J Biol Chem. 2004;279:19948-19954.

39. Levkovitch-Verbin H, Kalev-Landoy M, Habot-Wilner Z, Melamed S. Minocycline delays death of retinal ganglion cells in experimental glaucoma and after optic nerve transection. Arch Ophthalmol. 2006; 124:520-526.

40. Kernt M, Kampik A. Intraocular caspofungin: In vitro safety profile for human ocular cells. Mycoses. Feb 19, 2010. [Epub ahead of print].

41. Kernt M, Liegl RG, Rueping J, et al. Sorafenib protects human optic nerve head astrocytes from light-induced overexpression of vascular endothelial growth factor, platelet-derived growth factor, and placenta growth factor. Growth Factors. Feb 19, 2010. [Epub ahead of print].

42. Kernt M, Neubauer AS, Ulbig MW, Kampik A, Welge-Lussen U. In vitro safety of intravitreal moxifloxacin for endophthalmitis treatment. $J$ Cataract Refract Surg. 2008;34:480-488.

43. Siegner A, May CA, Welge-Lussen UW, Bloemendal H, LutjenDrecoll E. Alpha B-crystallin in the primate ciliary muscle and trabecular meshwork. Eur J Cell Biol. 1996;71:165-169.

44. Welge-Lussen U, Eichhorn M, Bloemendal H, Lutjen-Drecoll E. Classification of human scleral spur cells in monolayer culture. Eur J Cell Biol. 1998;75:78-84.

45. Mosmann T. Rapid colorimetric assay for cellular growth and survival: Application to proliferation and cytotoxicity assays. J Immunol Methods. 1983;65:55-63. 
46. Welge-Lussen U, May CA, Eichhorn M, Bloemendal H, Lutjen-Drecoll E. Alpha B-crystallin in the trabecular meshwork is inducible by transforming growth factor-beta. Invest Ophthalmol Vis Sci. 1999; 40:2235-2241.

47. Kahn MG, Giblin FJ, Epstein DL. Glutathione in calf trabecular meshwork and its relation to aqueous humor outflow facility. Invest Ophthalmol Vis Sci. 1983;24:1283-1287.

48. De La Paz MA, Epstein DL. Effect of age on superoxide dismutase activity of human trabecular meshwork. Invest Ophthalmol Vis Sci. 1996;37:1849-1853.

49. Levine AJ. p53, the cellular gatekeeper for growth and division. Cell. 1997;88:323-331.

50. McKinnon SJ, Lehman DM, Kerrigan-Baumrind LA, et al. Caspase activation and amyloid precursor protein cleavage in rat ocular hypertension. Invest Ophthalmol Vis Sci. 2002;43:1077-1087.

51. Miyashita T, Reed JC. Tumor suppressor p53 is a direct transcriptional activator of the human bax gene. Cell. 1995;80:293-299.

52. Miyashita T, Harigai M, Hanada M, Reed JC. Identification of a p53dependent negative response element in the bcl-2 gene. Cancer Res. 1994;54:3131-3135.

53. Hockenbery DM. The bcl-2 oncogene and apoptosis. Semin Immunol. 1992;4:413-420.

54. Deveraux QL, Takahashi R, Salvesen GS, Reed JC. X-linked IAP is a direct inhibitor of cell-death proteases. Nature. 1997;388:300-304.

55. Holcik M, Gibson H, Korneluk RG. XIAP: Apoptotic brake and promising therapeutic target. Apoptosis. 2001;6:253-261.

56. Sasaki T, Lopes MB, Hankins GR, Helm GA. Expression of survivin, an inhibitor of apoptosis protein, in tumors of the nervous system. Acta Neuropathol (Berl). 2002;104:105-109.

57. McKinnon SJ, Lehman DM, Tahzib NG, et al. Baculoviral IAP repeatcontaining-4 protects optic nerve axons in a rat glaucoma model. $\mathrm{Mol}$ Ther. 2002;5:780-787.
58. Petrin D, Baker A, Coupland SG, et al. Structural and functional protection of photoreceptors from MNU-induced retinal degeneration by the X-linked inhibitor of apoptosis. Invest Ophthalmol Vis Sci. 2003;44: 2757-2763.

59. Suzuki A, Ito T, Kawano H, et al. Survivin initiates procaspase 3/p21 complex formation as a result of interaction with Cdk4 to resist Fas-mediated cell death. Oncogene. 2000;19:1346-1353.

60. Suzuki A, Hayashida M, Ito T, et al. Survivin initiates cell cycle entry by the competitive interaction with Cdk4/p16(INK4a) and Cdk2/cyclin E complex activation. Oncogene. 2000;19:3225-3234.

61. Shin S, Sung BJ, Cho YS, et al. An anti-apoptotic protein human survivin is a direct inhibitor of caspase-3 and -7. Biochemistry. 2001;40: 1117-1123.

62. Neufeld AH. Nitric oxide: A potential mediator of retinal ganglion cell damage in glaucoma. Surv Ophthalmol. 1999;43 Suppl 1: S129-S135.

63. Kumar DM, Agarwal N. Oxidative stress in glaucoma: A burden of evidence. J Glaucoma. 2007;16:334-343.

64. Bjornberg A, Roupe G. Susceptibility to infections during long-term treatment with tetracyclines in acne vulgaris. Dermatologica. 1972;145: 334-337.

65. Margolis DJ. Antibiotics, acne, and upper respiratory tract infections. LDI Issue Brief. 2006;11:1-4.

66. Goulden V, Glass D, Cunliffe WJ. Safety of long-term high-dose minocycline in the treatment of acne. Br J Dermatol. 1996;134:693-695.

67. Topouzis F, Tranos P, Koskosas A, et al. Risk of sudden visual loss following filtration surgery in end-stage glaucoma. Am J Ophthalmol. 2005;140:661-666.

68. Agar A, Li S, Agarwal N, Coroneo MT, Hill MA. Retinal ganglion cell line apoptosis induced by hydrostatic pressure. Brain Res. 2006; 1086 : 191-200.
Clinical Ophthalmology

\section{Publish your work in this journal}

Clinical Ophthalmology is an international, peer-reviewed journal covering all subspecialties within ophthalmology. Key topics include: Optometry; Visual science; Pharmacology and drug therapy in eye diseases; Basic Sciences; Primary and Secondary eye care; Patient Safety and Quality of Care Improvements. This journal is indexed on

\section{Dovepress}

PubMed Central and CAS, and is the official journal of The Society of Clinical Ophthalmology (SCO). The manuscript management system is completely online and includes a very quick and fair peer-review system, which is all easy to use. Visit http://www.dovepress.com/ testimonials.php to read real quotes from published authors. 